посилення інтеграційної ролі андрагогічного й акмеологічного супроводу як цілісного і безперервного процесу вивчення, розвитку, саморозвитку пізнавальної сфери й особистості майбутнього соціального працівника, розробку і реалізацію відповідного змісту, моделей, технологій неперервної освіти.

Висновки. Зважаючи на вищевикладене, підсумуємо: засвоєння майбутніми соціальними працівниками теоретичних засад неперервної освіти передбачає моделювання розвивального акмеологічного середовища, що створює не лише теоретико-методологічне підгрунтя для розгортання наукового пошуку в сфері андрагогічної та акмеологічної проблематики, а й передбачає забезпечення ефективних умов для особистісного і професійного зростання особистості майбутнього соціального працівника, досягнення ним акме-вершин у сфері професійної майстерності.

\section{СПИСОК ВИКОРИСТАНОЇ ЛІТЕРАТУРИ}

1. Алибекова Г. 3. Учебно-педагогические комплексы в системе непрерывного образования / Г. 3. Алибекова // Советская педагогика. - 1992. № 9,10. - С. 54-60.
2. Ананьев Б. Г. О проблемах современного человекознания / Б. Г. Ананьев. - М. : Наука, 1977. - 379 с.

3. Антов Н. А. Непрерывное образование и вуз / Н. А. Антов. - М. : Наука, 1989.

4. Владиславлев А. П. В поисках концепции / А. П. Владиславлев // Вестник высшей школы. 1989. - № 26. - С. 48-50.

5. Концепція освіти дорослих в Україні / укл. Л. Б. Лук'янова. - Ніжин : ПП Лисенко М. М. 2011. -24 c.

6. Кузьмина Н. В. Акмеология качества профессиональной деятельности специалиста : монография / Н. В. Кузьмина, С. Д. Пожарский, Л. Е. Паутова. Санкт-Петербург ; Коломна ; Рязань, 2008. - 376 с.

7. Ничкало Н. Г. Неперервна професійна освіта як філософська та педагогічна категорія / Н. Г. Ничкало // Неперервна професійна освіта: теорія і практика. - 2011. - Вип. 1. - С. 9-22.

8. Освіта дорослих: теоретичні та методологічні засади : [монографія] / авт. кол. : Л. Б. Лук'янова, Л. С. Сігаєва, О. В. Аніщенко та ін. - К. : Педагогічна думка, 2012. -420 с.

Дата надходження до редакиї: 26.07.2019 p.

Наталія СУШИК,

кандидат педагогічних наук, доиент кафедри соиіальної роботи та педагогіки вищзої школи Східноєвропейського національного університету імені Лесі Українки, м. Луиьк

\title{
КОМПЕТЕНТНІСНИЙ ПІДХІД У РЕАЛІЗАЦІЇ ТЕХНОЛОГІЇ ФОРМУВАННЯ ЗДОРОВОГО СПОСОБУ ЖИТТЯ ДІТЕЙ ПІДЛІТКОВОГО ТА ЮНАЦЬКОГО ВІКУ З ВИКОРИСТАННЯМ МЕТОДУ «РІВНИЙ - РІВНОМУ»
}

У статті визначено сутність та ознаки технологї соиіального виховання особистості. Розроблено характеристику технології формування здорового способу життя дітей підліткового та юнацького віку з використанням методу "рівний - рівному» на основі компетентнісного підходу. Запропоновано практичні рекомендації для сочіальних педагогів $i$ фахівиів із соиіальної роботи з метою підвищення ефективності застосування означеної технологї.

Ключові слова: сочіальне виховання, технологіі соиіального виховання, соиіальний досвід особистості, компетентнісний підхід, компетентність, компетениія, здоров'язбережувальна, комунікативна, правова, життєва компетентності особистості, технологія формування здорового способу життя дітей підліткового та юнацького віку з використанням методу «рівний - рівному».

В статье определень сущиность и признаки технологии социального воспитания личности. Охарактеризована технология формирования здорового образа жизни детей подросткового и юношеского возраста с использованием метода «равный - равному» на основе компетентностного подхода. Предложены практические рекомендации для сочиальных педагогов и специалистов по сочиальной работе $c$ иелью повышения эффективности применения этой технологии. 
Ключевые слова: социальное воспитание, технологии социильного воспитания, социальный опыт личности, компетентностный подход, компетентность, компетениия, компетентность сохранения здоровья, коммуникативная, правовая, жизненная компетентности личности, технология формирования здорового образа жизни детей подросткового и юноческого возраста с использованием метода «равный - равному».

This article describes an essence and futures in technology of social building of personality: conceptualism, diagnostics, standardization, results, interaction, universality, optimization, control. The article defines that contemporary technologies of social education applying competent way focused on achieving a relevant, rational, effective social experience of personality. It consists of $d y$ namic combination of competence that defines capability of the person to successfully adapt into social life and be able to engage in educational, professional and other types of social activities. Explained competent approach in realization of technology of forming the healthy way of living among teenagers and students using the method of «equal to equal». Technology of forming of healthy way of living among teenagers and students by using the method: "equal to equal» is a technology of social education of personality, concentrated of forming physical, psychological, spiritual, socially healthy personality. Tasks of this technology are forming health sufficient, communicative, lawful life skills among the children and teenagers. Created a characteristic of technology of forming the healthy way of living among teenagers and students using the method of "equal to equal» on the ground of competent approach. Defined practical recommendations for counselors and social workers in order of raising of effectiveness of implementation of the described technology.

Key words: social education, technology of social education, social experience of personality, technology of forming the healthy way of living among teenagers and students using the method of «equal to equal».

Постановка проблеми. Результатом застосування технологій соціального виховання особистості $\epsilon$ формування динамічної комбінації компетентностей (здоров’язбережувальної, життєвої, соціальної, правової, комунікативної, інформаційної та ін.).

Під соціальним вихованням у широкому змісті цього поняття розуміють цілеспрямований розвиток, формування особистості під впливом об'єктивних і суб'єктивних факторів соціального середовища; у вузькому - цілеспрямований виховний вплив на свідомість, почуття, поведінку особистості з метою формування соціальних цінностей, ціннісних орієнтацій, знань, переконань, умінь, навичок поведінки, якостей, здатності застосовувати соціальний досвід у власній життєдіяльності [6, с. 112-115].

Соціальний досвід особистості повинен відповідати таким критеріям, як:

1) актуальність - забезпечує задоволення та реалізацію біологічних і соціальних потреб людини;

2) раціональність - включає чіткі, конкретні алгоритми дій людини з метою досягнення результату;

3) ефективність - забезпечує досягнення найкращого результату;

4) оптимальність щодо використання часу, засобів, зусиль.

На нашу думку, для визначення терміна «mexнології соціального виховання" як системи обгрунтованих наукою алгоритмів, форм, методів, засобів, застосування яких забезпечує досягнення ефективних і оптимальних результатів соціального виховання особистості доцільно використати науковий підхід І. П. Підласого [5].

Ми вважаємо, що ефективність та оптимальність соціального виховання особистості забезпечується завдяки застосуванню технологій соціального виховання, оскільки для них характерні такі ознаки (за I. М. Дичківською) [3]:

1) концеептуальність - розроблення та застосування технології соціального виховання особистості на основі наукових концепцій;

2) діагностичність - проведення діагностики об'єкта з метою визначення мети, завдання, змісту, форм, методів, засобів, очікуваних результатів соціального виховання особистості та перевірки ефективності застосування конкретної технології;

3) стандартизованість - технологія соціального виховання особистості завжди передбачає чітку послідовність етапів із використанням визначених і науково обгрунтованих форм, методів, засобів відповідно до конкретних умов;

4) результативність - гарантоване досягнення ефективних результатів за оптимальних затратах відповідно до визначеної мети соціального виховання;

5) інтерактивність - застосування інтерактивних форм, методів, засобів соціального виховання на основі суб' єкт-суб'єктного принципу спілкування;

6) універсальність - здатність ефективного й оптимального відтворення конкретної технології соціального виховання особистості, зокрема компетентним соціальним педагогом $33 \mathrm{CO}$, в якому створенні умови для iіi реалізації;

7) оптимальність - раціональне використання ресурсів, часу, праці соціальних педагогів, фахівців iз соціальної роботи і досягнення запланованих результатів;

8) керованість - чітке проектування, планування, організація, реалізація технології соціального виховання особистості, постійний зворотний зв'язок між його суб'єктами, орієнтований на чітко визначений результат;

9) контрольованість - поетапна діагностика результативності соціального виховання, динаміки рівня сформованості соціальних цінностей, ціннісних орієнтацій, знань, умінь, навичок поведінки, якостей особистості.

Аналіз наукових досліджень і публікацій. Із метою обгрунтування компетентнісного підходу в реалізації технологій соціального виховання особистості, зокрема технології формування здорового способу життя дітей підліткового та юнацького віку з використанням методу «рівний - рівному», нами було проаналізовано наукові праці в таких аспектах: сутність, особливості, структура, види, етапи, фактори, механізми соціалізації особистості (А. В. Мудрик); сутність, особливості, етапи технологій виховання особистості (І. П. Підласий); сутність, ознаки інноваційних педагогічних технологій (I. М. Дичківська); технологія формування здорового способу життя дітей підліткового та юнацького віку з використанням методу «рівний - рівному» (Т. П. Авельцева, О. В. Безпалько, О. А. Голоцван, Н. В. Зимівець, Н. О. Лещук, Ж. В. Савич та ін.).

Мета статті - обгрунтувати застосування компетентнісного підходу в ході реалізації технології формування здорового способу життя дітей підліткового та юнацького віку з використанням методу «рівний рівному». 
Виклад основного матеріалу. Сучасні технології соціального виховання реалізують компетентнісний підхід, зорієнтований на здобуття актуального, раціонального, ефективного, оптимального соціального досвіду особистості, який передбачає динамічну комбінацію компетентностей, що визначає здатність особи успішно соціалізуватися, здійснювати навчальну, професійну та інші види діяльності.

Технологія формування здорового способу життя дітей підліткового та юнацького віку з використанням методу «рівний - рівному» - це технологія соціального виховання особистості, спрямована на розвиток, формування фізично, психічно, духовно, соціально здорової особистості [4, с. 5]. Завданнями цієї технології є формування здоров'язбережувальної, комунікативної, правової, життєвої компетентностей дітей підліткового та юнацького віку.

Компетентність - це сукупність цінностей, ціннісних орієнтацій, знань, переконань, умінь, навичок поведінки, здатність особистості застосувати їх у реальних життєвих ситуаціях.

Згідно із Державним стандартом базової і повної загальної середньої освіти «здоров'язбережувальна компетентність - це здатність особистості застосовувати в умовах конкретної ситуації сукупність здоров'язбережувальних компетенцій, відповідально ставитися до власного здоров'я та здоров'я інших людей» [2].
Комунікативна компетентність - здатність особистості ефективно й оптимально спілкуватися 3 людьми в різних життєвих ситуаціях.

Правова компетентність - Здатність особистості усвідомлено, відповідально, активно й ефективно реалізовувати права та обов'язки в усіх сферах життєдіяльності.

Життева компетентність - здатність особистості успішно розв'язувати актуальні завдання в усіх сферах життєдіяльності, спрямовувати соціальні та особистісні ресурси на самовдосконалення (самопізнання, саморозвиток, самоосвіту, самовиховання).

Ми вважаємо, що вид компетентності передбачає формування інтегрованої сукупності компетенцій, наприклад: 1) здоров'язбережувальна компетентність - інтегрована сукупність здоров'язбережувальних компетенцій; 2) комунікативна компетентність - інтегрована сукупність комунікативних компетенцій; 3) правова компетентність - інтегрована сукупність правових компетенцій 4) життєва компетентність - інтегрована сукупність життєвих компетенцій особистості.

Із метою ефективної реалізації технології формування здорового способу життя дітей підліткового та юнацького віку з використанням методу «рівний - рівному» соціальними педагогами, педагогами закладів загальної середньої освіти, позашкільної освіти, фахівцями із соціальної роботи пропонуємо їі характеристику на основі компетентнісного підходу (див. табл.).

Таблиия

Характеристика технології формування здорового способу життя дітей підліткового та юнацького віку з використанням методу «рівний - рівному» на основі компетентнісного підходу

\begin{tabular}{|c|c|c|c|}
\hline $\begin{array}{l}\text { № } \\
\text { 3/II }\end{array}$ & Компоненти технології & \multicolumn{2}{|c|}{ Характеристика компонентів технології } \\
\hline 1 & Об’єкт технології & \multicolumn{2}{|c|}{ діти підліткового (10-14 років) та юнацького (15-18 років) віку } \\
\hline 2 & Суб’єкти реалізації технології & \multicolumn{2}{|c|}{$\begin{array}{l}\text { соціальні педагоги, педагоги закладів загальної середньої освіти, } \\
\text { позашкільної освіти, фахівці із соціальної роботи }\end{array}$} \\
\hline 3 & Мета технології & \multicolumn{2}{|c|}{$\begin{array}{l}\text { розвиток, формування фізично, психічно, духовно, соціально здорової } \\
\text { особистості }\end{array}$} \\
\hline 4 & Завдання технології & \multicolumn{2}{|c|}{$\begin{array}{l}\text { формування компетентностей (здоров'язбережувальної, комунікатив- } \\
\text { ної, правової, життєвої) дітей підліткового та юнацького віку }\end{array}$} \\
\hline \multirow[t]{11}{*}{5} & Зміст технології & \multicolumn{2}{|c|}{$\begin{array}{l}\text { 1) формування здоров'язбережувальної компетентності дітей } \\
\text { підліткового та юнацького віку: }\end{array}$} \\
\hline & \multirow{3}{*}{$\begin{array}{l}\text { Модуль 2. «Я та моє здоров'я». } \\
\text { Модуль 3. «Я дорослішаю» } \\
\text { (для дітей 10-11 років). }\end{array}$} & \begin{tabular}{|c|} 
цінність \\
\end{tabular} & здоров'я людини \\
\hline & & ціннісна орієнтація & збереження та зміцнення здоров’я людини \\
\hline & & знання & $\begin{array}{l}\text { сутність, складові, показники здоров’я (фізичне, } \\
\text { психічне, духовне, соціальне) та здорового спо- } \\
\text { собу життя }\end{array}$ \\
\hline & \multirow{3}{*}{$\begin{array}{l}\text { Модуль 3. «Твоє життя - твій } \\
\text { вибір»; } \\
\text { Модуль 4. «Прояви турботу і } \\
\text { обачливість» (для дітей 12-14 } \\
\text { та 15-18 років) }\end{array}$} & переконання & відповідальне ставлення до здоров’я \\
\hline & & $\begin{array}{l}\text { уміння, } \\
\text { навички }\end{array}$ & $\begin{array}{l}\text { дотримання здорового способу життя (раціональ- } \\
\text { не планування режиму дня, здоровий сон, збалан- } \\
\text { соване харчування, активна рухова діяльність } \\
\text { тощо); відповідальної, безпечної поведінки в } \\
\text { ситуаціях ризику для здоров’я }\end{array}$ \\
\hline & & здатність & $\begin{array}{l}\text { відповідально, безпечно поводитися в різнома- } \\
\text { нітних життєвих ситуаціях }\end{array}$ \\
\hline & \multirow{4}{*}{\begin{tabular}{|ll} 
Модуль 1. «Я вчуся спілкува- \\
тися» (для дітей 10-11 років). \\
Модуль 2. «Спілкуємося \\
діємо» (для дітей & $12-14$ \\
$15-18$ років)
\end{tabular}} & \multicolumn{2}{|c|}{$\begin{array}{l}\text { 2) формування комунікативної компетентності дітей підлітко- } \\
\text { вого та юнацького віку: }\end{array}$} \\
\hline & & \begin{tabular}{|c|} 
цінність \\
\end{tabular} & спілкування \\
\hline & & ціннісна оріснтація & ефективне спілкування \\
\hline & & знання & $\begin{array}{l}\text { сутність, структура, принципи, види, функції, } \\
\text { стилі спілкування; причини виникнення, стадії } \\
\text { розвитку конфліктів, стратегії, методи, засоби їх } \\
\text { ефективного розв'язання }\end{array}$ \\
\hline
\end{tabular}


Продовження таблииі

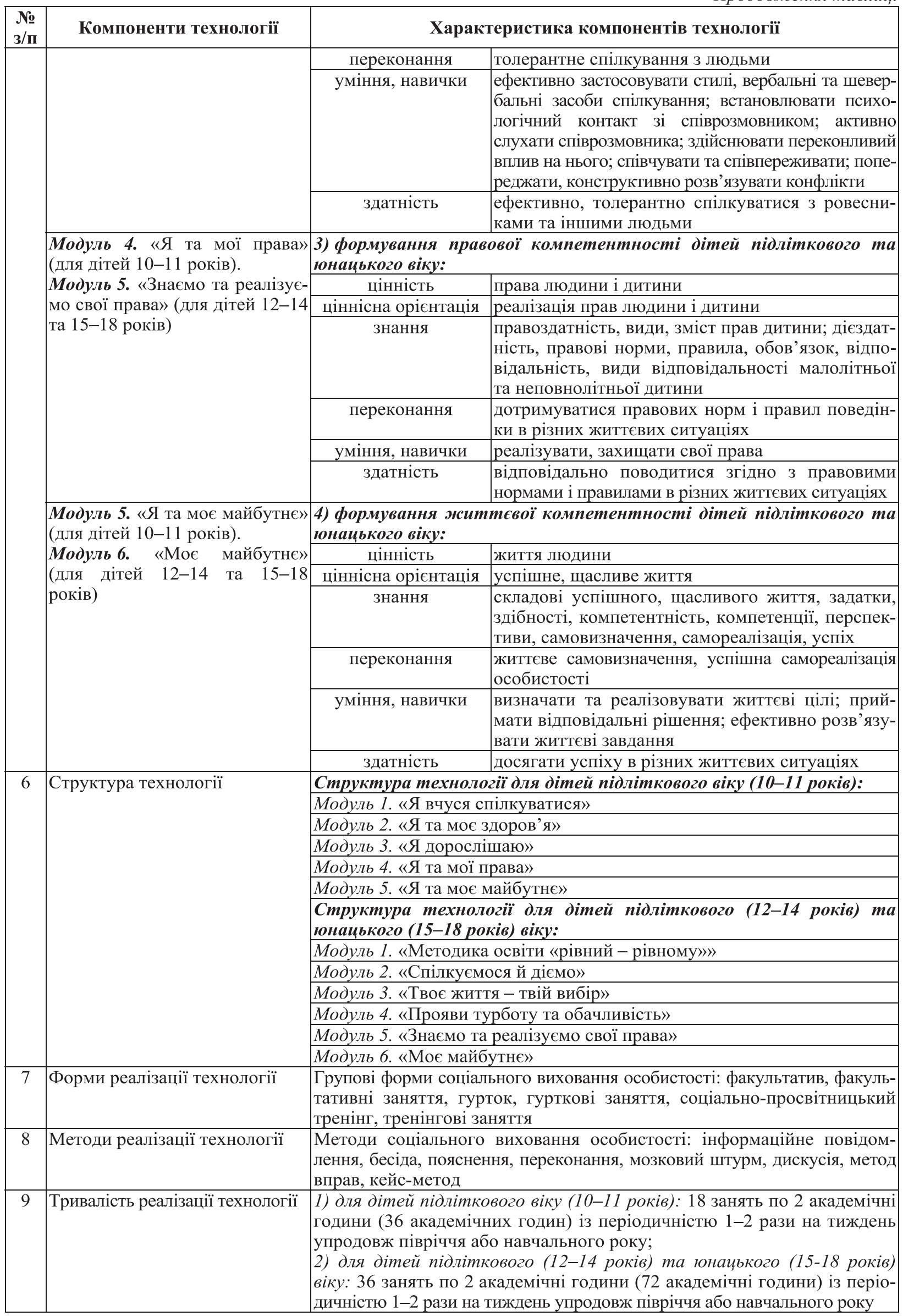


Продовження таблииі

\begin{tabular}{|c|c|c|}
\hline $\begin{array}{l}\text { № } \\
\text { 3/II }\end{array}$ & Компоненти технології & Характеристика компонентів технології \\
\hline 10 & $\begin{array}{l}\text { Навчально-методичне } \\
\text { забезпечення технології }\end{array}$ & $\begin{array}{l}\text { 1) Голоцван О. А. Я - моє здоров’я - моє життя: навч.-метод. посіб. / } \\
\text { О. А. Голоцван. - К. : Навч. книга, 2005. - } 247 \text { с. } \\
\text { 2) Лещук Н. О. Програма факультативного курсу «Сприяння } \\
\text { просвітницькій роботі «рівний - рівному» серед молоді України щодо } \\
\text { здорового способу життя: навч.-метод. посіб. / Н. О. Лещук, } \\
\text { Ж. В. Савич. - К. : Наш час, 2007. - } 52 \text { с. } \\
\text { 3) Спілкуємося й діємо : навч.-метод. посіб. / Ж. В. Савич, О. В. Без- } \\
\text { палько. - К. : Наш час, 2006. - } 120 \text { с. } \\
\text { 4) Твоє життя - твій вибір : навч.-метод. посіб. / З. А. Сивогракова, } \\
\text { Н. О. Лещук, Н. В. Зимівець, Т. П. Авельцева, І. Г. Сомова. - К. : Наш } \\
\text { час, 2006. - } 167 \text { с. } \\
\text { 5) Прояви турботу і обачливість: навч.-метод. посіб. / О. А. Голоцван, } \\
\text { Б. М. Ворник. - К. : Наш час, 2007. - 232 с. } \\
\text { 6) Знаємо та реалізуємо свої права: навч.-метод. посіб. / С. Ф. Константі- } \\
\text { нов, Я. М. Квітка, Ж. В. Савич, Н. О. Лещук. -К. : Наш час, 2007. - } 224 \text { с. } \\
\text { 7) Моє майбутнє : навч.-метод. посіб. / Ж. В. Савич, З. А. Сивогра- } \\
\text { кова, Н. О. Лещук. - К. : Наш час, 2007. - } 48 \text { с. }\end{array}$ \\
\hline
\end{tabular}

До основних етапів упровадження технології формування здорового способу життя дітей підліткового та юнацького віку з використанням методу «рівний - рівному» відносимо такі основні складові:

1. Діагностика доцільності використання технології з метою розв'язання певної проблеми на локальному, місцевому, регіональному, державному рівнях.

2. Розроблення й адаптація навчально-методичних матеріалів для занять 3 дітьми підліткового та юнацького віку.

3. Відбір і навчання фахівців (педагогів-тренерів) для роботи 3 використанням методу «рівний - рівномy».

4. Навчання дітей підліткового та юнацького віку із залученням їх до участі в тренінгах.

5. Відбір дітей підліткового та юнацького віку для підготовки їх до роботи з однолітками.

6. Мотивація та підтримка дітей-інструкторів.

7. Організація діяльності дітей підліткового та юнацького віку серед однолітків.

8. Моніторинг діяльності дітей-інструкторів $[4$, c. 10$]$.

Отже, умови ефективної реалізації технології формування здорового способу життя дітей підліткового та юнацького віку з використанням методу «рівний - рівному» передбачають: 1) реалізацію технології на локальному, місцевому, регіональному, державному рівнях; 2) залучення до реалізації технології компетентних соціальних педагогів, фахівців із соціальної роботи; 3) забезпечення високого рівня підготовки педагогів-тренерів, дітей-інструкторів; 4) ефективне й оптимальне соціальне виховання дітей підліткового та юнацького віку однолітками-інструкторами з використанням методу «рівний - рівному»; 5) оптимальне забезпечення навчально-методичними матеріалами; 6) ефективне використання фінансових, матеріальних, технічних ресурсів.

Висновки. Таким чином, технологія формування здорового способу життя дітей підліткового та юнацького віку з використанням методу «рівний - рівному»-це технологія соціального виховання, спрямована на розвиток, формування фізично, психічно, духовно, соціально здорової особистості. Завданнями означеної технології є формування здоров'язбережувальної, комунікативної, правової, життєвої компетентностей дітей підліткового та юнацького віку.

Перспективи подальших досліджень передбачають наукове обгрунтування сутності, структури, змісту здоров'язбережувальної, життєвої, соціальної, правової, комунікативної та інших компетентностей особистості.

\section{СПИСОК ВИКОРИСТАНОЇ ЛІТЕРАТУРИ}

1. Голоцван О. А. Я - моє здоров'я - моє життя : навч.-метод. посіб. / О. А. Голоцван. - К. : Навч. книга, 2005. - 247 с.

2. Державний стандарт базової і повної загальної середньої освіти від 23.11.2011 № 1392. URL: https:// zakon.rada.gov.ua/laws/show/1392-2011-\%D0\%BF (дата звернення: 27.09.2019).

3. Дичківська I. М. Інноваційні педагогічні технології : навч. посіб. / І. М. Дичківська. - К. : Академвидав, 2004. -352 с.

4. Лещук Н. О. Програма факультативного курсу «Сприяння просвітницькій роботі «рівний - рівному» серед молоді України щодо здорового способу життя» : навч.-метод. посіб. / Н. О. Лещук, Ж. В. Савич. - К. : Наш час, 2007. - 52 с.

5. Подласый И. П. Педагогика. Новый курс : учебник для студ. пед. вузов : в 2 кн. Кн. 2. Процесс воспитания / И. П. Подласый. - М. : ВЛАДОС, 1999. - 256 с.

6. Сушик Н. С. Сутність і мета технологій соціального виховання особистості / Н. С. Сушик // Науковий часопис Національного педагогічного університету імені М. П. Драгоманова. - 2018. Вип. 24(1). - С. 109-117. - (Серія 11 «Соціальна робота. Соціальна педагогіка»). URL: http://nbuv.gov.ua/ UJRN/Nchnpu 0112018 24(1) 18 (дата звернення: 27.09.2019).

Дата надходження до редакиї: 29.09.2019 p. 